\section{In Vitro Analysis of the Cytotoxicity of Indirect Restorative Materials}

Miriam Zaccaro Scelza ${ }^{1}$, Isleine Portal Caldas², Jhony Medeiros de Mattos ${ }^{3}$, Felipe Oliveira ${ }^{3}$, Waldimir Carvalho ${ }^{4}$, Gutemberg Gomes Alves ${ }^{5}$

\begin{abstract}
This study aimed to compare the cytotoxicity of the Vita AC12, Lava Ultimate, Vita Enamic and InSync indirect restorative materials. Extracts of each material were prepared by incubation for 1, 7 and 40 days, with daily washing. Human gingival fibroblasts were exposed to the extracts, and cell viability was evaluated by sequential assessment of mitochondrial activity (XTT), membrane integrity (NRU) and cell density (CVDE). Extracts of polystyrene beads and latex fragments were used as negative and positive controls, respectively. Differences between groups and experimental times were evaluated by analysis of variance. At the $24 \mathrm{~h}$ extraction, significant differences between the control and both Vita AC-12 and InSync were observed in the XTT assay $(p<0.05)$, and between the control and both Enamic and Lava Ultimate, in the CVDE assay ( $p<0.05)$. AC12, Lava Ultimate, and InSync presented significantly lower cell viability than Enamic and the control group, in the NRU assay $(p<0.05)$. The Vita Enamic and Lava Ultimate hybrid ceramic-like materials presented better biocompatibility at the $24 \mathrm{~h}$ extraction time point than the $\mathrm{AC} 12$ and InSync ceramic materials. However, a simulation of the removal of toxic components by biological fluids, conducted by using longer extraction times and daily washing, led to the absence of cytotoxicity in all the tested restorative materials. These findings can be viewed as positive for the clinical indication of these restorative materials, considering their contact with adjacent soft tissues for extended periods of time.
\end{abstract}

\author{
${ }^{1}$ Department of Endodontics and \\ Geriatric Dentistry, School of \\ Dentistry, UFF - Universidade Federal \\ Fluminse, Niterói, RJ, Brazil \\ ${ }^{2}$ Doctoral Program in Dentistry, \\ UFF - Universidade Federal \\ Fluminse, Niterói, RJ, Brazil \\ ${ }^{3}$ Laboratory of Experimental Cell \\ Culture (LECCel), UFF - Universidade \\ Federal Fluminse, Niterói, RJ, Brazil \\ ${ }^{4}$ Department of Prosthodontics, \\ School of Dentistry, UFF - \\ Universidade Federal Fluminse, \\ Niterói, RJ, Brazil \\ ${ }^{5}$ Department of Molecular and \\ Cell Biology, Institute of Biology, \\ UFF - Universidade Federal \\ Fluminse, Niterói, RJ, Brazil
}

Correspondence: Dr. Gutemberg Alves, Rua Marques de Paraná, 303, $4^{\circ}$ andar, Niterói, RJ, Brasil. Tel: +55-21-2629-9255. e-mail: gutopepe@yahoo.com.br

\author{
Key Words: dental porcelain \\ prosthodontics, toxicity \\ tests, biocompatible \\ materials, fibroblasts.
}

\section{Introduction}

For decades, full-crown restorations have been used to preserve the masticatory function and aesthetics of destroyed natural teeth. Metal-ceramic crowns have been the restoration of choice (1) for many professionals, owing to their high strength, precise adjustment, marginal integrity and extended lifetime. However, in vitro assays have shown that dental casting alloys may present cytotoxicity, mostly through the release of components into the cell culture media (2). This toxicity, together with the need for more resistant materials, led to the development of novel nonmetal aesthetic materials. These indirect aesthetic materials, used for the reconstruction of extensively destroyed teeth, can be classified into dental ceramics (glass-matrix ceramics and polycrystalline ceramics) and ceramic-like materials (resin-matrix ceramics) (3).

Among the dental ceramics, zirconia was introduced with the purpose of meeting the requirements of aesthetics and resistance, and its use has been widely disseminated in conjunction with computer-aided design/ computer-assisted manufacturing (CAD/CAM) systems (4). Resin-matrix ceramics or indirect composites for CAD/CAM applications can be classified according to their microstructure into dispersed fillers (zirconia-silica nanofillers and organic matrix) and polymer-infiltratedceramic-networks (PICNs), based on the infiltration of a pre- sintered glass-ceramic scaffold with a polymeric material (5). PICNs constitute an innovative class of CAD/CAM materials offering promising perspectives in prosthodontics (6) since these materials present better fracture toughness and flexural strength than classical composites (7).

One such dispersed filler material is Lava Ultimate. Just like a composite resin, this material is not brittle and therefore resists fracturing. Since it is also a glass ceramic, it has excellent polish retention, as well as long-lasting aesthetics (5). Vita Enamic is another PICN, based on a nano-hybrid composite resin reinforced with glass fibers. According to the manufacturer, the dominant ceramic is enhanced by a polymer network, creating a material that exhibits the positive characteristics of both ceramics and composite resins for use as dental prostheses on natural teeth, and, more recently, on implants (8).

From a biological point of view, ceramics are good choices for restorative materials. A previous study (9) identified no release of potentially toxic elements from various ceramics in experiments using cell cultures. Also, biocompatibility studies conducted in animals have demonstrated similar soft tissue integration results for alumina, zirconia, and titanium (10). On the other hand, the in vitro cellular responses to several types of dental ceramics in use have not always been favorable (11). The CAD/CAMmilled, all-ceramic materials used in implant abutments 
come in close contact with oral soft tissues such as the keratinized marginal gingiva, which may raise concerns about the safety and biocompatibility of these products (4). According to Tassin et al. (12), significant cytotoxicity may be observed for conventional composites, while PICNs such as Vita Enamic proved to be very biocompatible during in vitro assays.

Consequently, the high variability of the physicochemical characteristics of indirect aesthetic materials may lead to controversy regarding their biocompatibility, reinforcing the relevance of in vitro standardized testing of novel ceramic materials. In this context, InSync is a recently launched layering ceramic system that, according to the manufacturer, is indicated for zirconia and lithium disilicate restorations, and can be employed for both conventional and implant-supported prostheses (13), for which there are no studies in the scientific literature assessing its biocompatibility or in vitro cytotoxicity.

Therefore, the aim of this study was to evaluate and compare the cytotoxicity of the representatives of different classes of aesthetic materials, namely: Lava Ultimate (UDMA composite dispersed filler), Vita Enamic (UDMA + TEGDMA glass-fiber nano-hybrid PICN), Vita AC12 (inlay CAD/ CAM ceramic) and InSync (layering ceramic), employing a standardized multiparametric assay with a human primary gingival fibroblast model.

\section{Material and Methods}

This study was approved by the local Institutional Research Ethics Committee (CAAE 50319115.0.0000.5243).

\section{Sample Preparation}

The following materials were tested in this study: Vita Enamic (VITA Zahnfabrik, Bad Säckingen, Germany), Lava Ultimate (3M ESPE, St. Paul, MN, USA), Vita AC-12 (VITA Zahnfabrik, Bad Säckingen, Germany), and InSync (Chemical, Vaduz, Liechtenstein) (Table 1).
The materials were ground, powdered, and only then weighed, to increase their contact surface with the culture medium, as described for irregularly shaped solid devices in ISO 10993-5:2009 (14). A sample of $0.2 \mathrm{~g}$ of each material was immersed into $1 \mathrm{~mL}$ of DMEM-high glucose culture medium added with 10\% Fetal Bovine Serum (FBS; GibcoInvitrogen, Grand Island, NY, USA) at $37^{\circ} \mathrm{C}$, in a humidified atmosphere of $95 \%$ air and 5\% CO2, for the time periods of either $24 h, 7$ days or 40 days. The conditioned culture medium underwent daily renewal with fresh medium to simulate the effects of gingival crevicular fluid washing the material in the patient's mouth.

\section{Cell Culture and Exposure}

Primary cells were collected from a male and female. The participants were patients of the Dentistry Clinic at the Fluminense Federal University, who met the following criteria: subjects who were indicated for surgery that allowed the collection of a gingival fragment without affecting the original surgical plan, who had no chronic disease, made no continuous use of drugs and had no gingival bleeding. Human gingival fibroblast (HGF) cultures were isolated from gingival fragments according to a previously established protocol (15).

Cells at the second passage were cultured in a DMEMhigh glucose medium (Cultilab, Campinas, SP, Brazil) supplemented with 10\% FBS (Gibco-Invitrogen, Grand Island, NY, USA) and two antibiotics, namely 10,000 IU/ $\mathrm{mL}$ penicillin and $10 \mathrm{mg} / \mathrm{mL}$ streptomycin. Cells were then seeded in 96-well culture plates at an initial density of 3 $\times 104$ cells per well, followed by incubation for $24 \mathrm{~h}$ at $37^{\circ} \mathrm{C}$ under 5\% $\mathrm{CO} 2$.

Subsequently, the cell cultures were exposed to the test samples by replacing $180 \mu \mathrm{L}$ of the medium in each well with $180 \mu \mathrm{L}$ of one of the test material extracts and then incubated for $24 \mathrm{~h}$. Extracts of latex fragments, with well-known toxicity, were employed as a positive control,

Table 1. Description of the materials tested in the study

\begin{tabular}{|c|c|c|}
\hline $\begin{array}{l}\text { Product and } \\
\text { manufacturer }\end{array}$ & Composition & Application \\
\hline $\begin{array}{l}\text { Vita Enamic } \\
\text { (VITA Zahnfabrik) }\end{array}$ & $\begin{array}{c}\text { Silicon dioxide }\left(\mathrm{SiO}_{2}\right) \text { 58-63\%; aluminum oxide }\left(\mathrm{AL}_{2} \mathrm{O}_{3}\right) \text { 20-23\%; sodium oxide } \\
\left(\mathrm{Na}_{2} \mathrm{O}\right) \text { 9-11\%; potassium oxide }\left(\mathrm{K}_{2} \mathrm{O}\right) 4-6 \% \text {; boron trioxide }\left(\mathrm{B}_{2} \mathrm{O}_{3}\right) 0.5-2 \% \text {; zirconium } \\
\text { dioxide }\left(\mathrm{ZrO}_{2}\right)<1 \% \text {; calcium oxide }(\mathrm{CaO})<1 \% \text {. (UDMA + TEGDMA) }\end{array}$ & CAD/CAM (Cerec) \\
\hline $\begin{array}{l}\text { Lava Ultimate } \\
\text { (3M ESPE) }\end{array}$ & $\begin{array}{c}\text { Composite resin material 20\% (UDMA) with } 80 \mathrm{wt} \% \text { silica and zirconia } \\
\text { nanoparticles and zirconia/silica nanoclusters }\end{array}$ & $\mathrm{CAD} / \mathrm{CAM}$ \\
\hline $\begin{array}{l}\text { Vita AC-12 } \\
\text { (VITA Zahnfabrik) }\end{array}$ & $\begin{array}{l}\text { Silicon dioxide }\left(\mathrm{SiO}_{2}\right) 15-17 \% \text {; aluminum oxide }\left(\mathrm{Al}_{2} \mathrm{O}_{3}\right) 14-17 \% \text {; boron } \\
\text { trioxide }\left(\mathrm{B}_{2} \mathrm{O}_{3}\right) 12-15 \% \text {; titanium dioxide }\left(\mathrm{TiO}_{2}\right) ; 3-5 \% \text {; lanthanum oxide } \\
\left(\mathrm{La}_{2} \mathrm{O}_{3}\right) 39-48 \% \text {; ceric oxide }\left(\mathrm{CeO}_{2}\right) 2-5 \% \text {; calcium oxide }(\mathrm{CaO}) 2-4 \%\end{array}$ & $\begin{array}{c}\text { CAD/CAM } \\
\text { (CELAY System) }\end{array}$ \\
\hline $\begin{array}{l}\text { InSync } \\
\text { (Chemichl) }\end{array}$ & $\begin{array}{l}\text { Silicon dioxide }\left(\mathrm{SiO}_{2}\right) \text { 55-75\%; aluminum oxide }\left(\mathrm{Al}_{2} \mathrm{O}_{3}\right) \text { 6-20\%; boron trioxide } \\
\left(\mathrm{B}_{2} \mathrm{O}_{3}\right) 10 \% \text {; potassium oxide }\left(\mathrm{K}_{2} \mathrm{O}\right) 3-12 \% \text {; sodium oxide }\left(\mathrm{Na}_{2} \mathrm{O}\right) \text { 3-12\%, lanthanum } \\
\text { oxide }\left(\mathrm{La}_{2} \mathrm{O}_{3}\right) \text { 0.05-4\%; ceric oxide }\left(\mathrm{CeO}_{2}\right) \text { 0.1-2\%; calcium oxide (CaO) 0-3\% }\end{array}$ & Build-up technique \\
\hline
\end{tabular}


whereas extracts of biocompatible high-density polystyrene beads were used as a negative control. The blank, unexposed group (cells plus culture medium) was exposed only to the culture media (DMEM-high glucose). Each condition was tested in three replicates and three different assays.

\section{Multiparametric in Vitro Assay}

After $24 \mathrm{~h}$ exposure of cells to the experimental groups and controls, cell viability was assessed using a multi-parametric assay kit (In-Cytotox, Xenometrix, Allschwil, Switzerland), which evaluates three different cell parameters sequentially in the same cell culture (16), as described below.

\section{Mitochondrial Activity (XTT)}

The multiparametric assessment began with the XT assay. XTT (2,3-bis [2-methoxy-4-nitro-5-sulfophenyl]$2 \mathrm{H}$-tetrazolium-5-carboxy aniline salt) is a tetrazolium salt that is converted to formazan through a succinate dehydrogenase system in the mitochondrial respiratory chain of viable cells. After addition of the reagent, the conversion of water-soluble yellow tetrazolium XTT salt into orange formazan was monitored by measuring the optical density (O.D.) at $480 \mathrm{~nm}$ on a UV/Vis microplate reader (Synergy II, BioTek Instruments, Winooski, VT, USA).

\section{Membrane Integrity (Neutral Red Uptake, NRU)}

The cells subjected to the XIT assay were washed twice with PBS and underwent the NRU assay, which determines the viable cell estimation through cellular membrane integrity. The NRU test is a survival/cell viability assay based on the ability of the cell to incorporate and retain the neutral red dye in the cell's lysosomes, which accumulates on its internal membrane. The cells were fixed after $3 \mathrm{~h}$ of incubation with the dye. NR dye was then extracted, and the optical density of the supernatant measured at $540 \mathrm{~nm}$, which is directly related to the proportion of viable cells (18).

\section{Cellular Density (Crystal Violet Dye Exclusion, CVDE)}

After conducting the NRU assay, the fixed cells were washed twice with PBS and evaluated by the CVDE assay, which quantifies nuclear DNA as a measure of cell density. After washing/removal of excess dye, optical density at $540 \mathrm{~nm}$ was directly proportional to the number of adherent cells in each well.

\section{Statistical Analysis}

Analysis of variance (one-way ANOVA) was used to test the interactions between three sources of variation (test material, assay type and time) and the proportions of viable cells for each test material, compared with those of the control groups. Statistical significance was set at $\alpha=0.05$. Tukey's post-test was performed to compare groups at a same given time point. All statistical analyses were performed with GraphPad Prism 6 (Graphpad Software, Inc., San Diego, CA, USA).

\section{Results}

The assay was internally validated by the behavior of the positive and negative controls, which promoted the expected levels of cell death and survival with all parameters assessed (Fig. 1). Regarding the test materials, significant differences $(p<0.05)$ were observed between

A

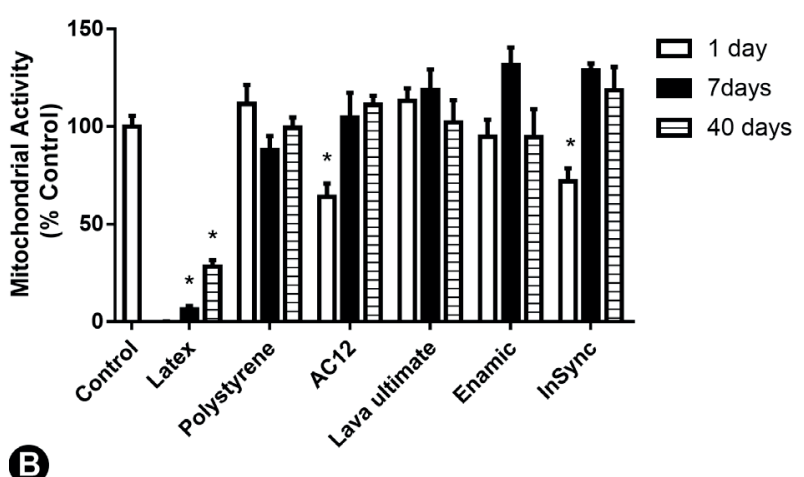

B
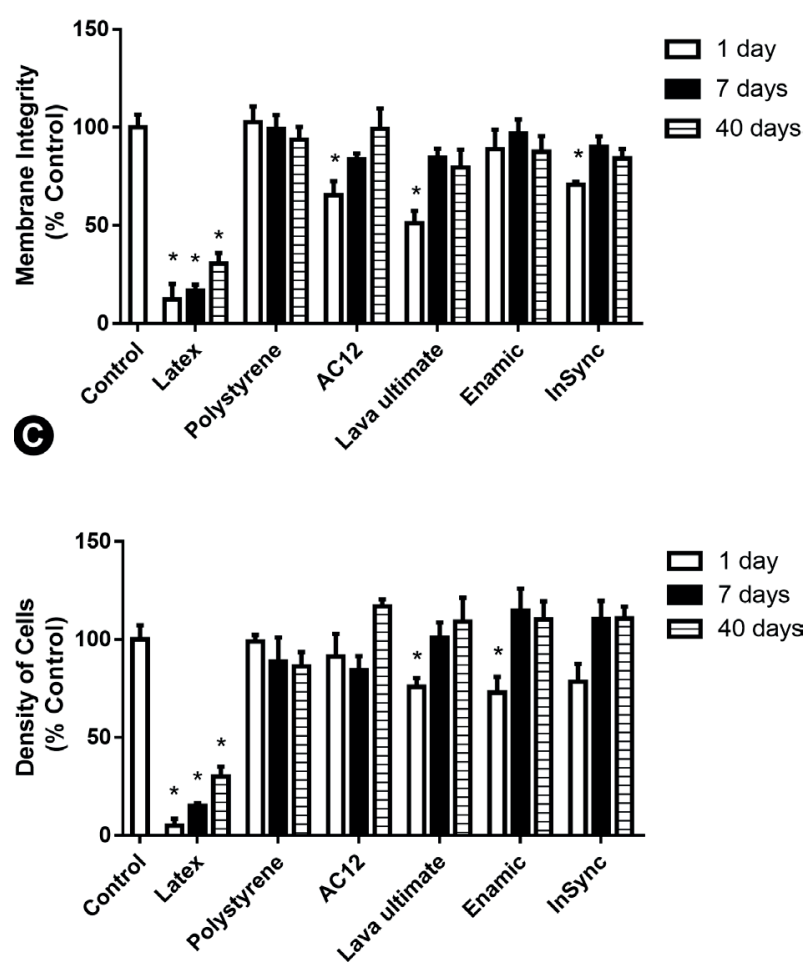

Figure 1. Cytotoxic effects of the materials tested on human gingival fibroblasts, as assessed by the XTT, NRU and CVDE assays, and expressed as a mean percentage of the control (cells exposed only to culture medium). The bars indicate mean \pm standard deviation. The asterisk indicates a significant difference compared with the control group $(\mathrm{p}<0.05)$. 
the blank group and both Vita AC-12 and InSync at the $24 \mathrm{~h}$ time point in the XT assay (Fig.1 A). Vita AC12, Lava Ultimate, and InSync presented significantly lower cell viability $(p<0.05)$ than Enamic and the blank group at the $24 \mathrm{~h}$ time point, in the NRU assay (Fig. 1B).

In the CVDE assay, Enamic and Lava Ultimate presented significantly lower cell viability when compared to the negative control $(p<0.05)$ at the $24 \mathrm{~h}$ time point (Fig. 1C).

All of the reduced levels of cell viability were considered borderline regarding the cutoff value of $70 \%$ defined by international standards (14). Furthermore, cellular viability increased after $24 \mathrm{~h}$ and was never lower than $75 \%$ at the 7 and 40 day time points for all the tested ceramic materials.

\section{Discussion}

The indirect restorative materials tested in the present study were designed to be used in close contact with gingival tissue and, therefore, to be biocompatible with gingival fibroblasts. Human gingival fibroblasts were chosen for the cytotoxicity assays as the in vitro model that best simulates this tissue response. In comparison with immortalized cell lines, HGFs provide results which are closer to those obtainable with cells of normal $\vec{s}$ phenotype behavior, thus constituting good candidates for in vitro biocompatibility tests of trans-gingival implant components (17).

Several techniques can be used to evaluate the in vitro cytotoxicity of dental materials. Those include advanced methodologies that present high sensitivity and specificity for the determination of adverse effects, including the use of flow cytometry, the determination of apoptosis, or assessments the release of inflammatory markers. Nevertheless, for a simple initial assessment of the cytotoxicity of restorative materials, one of the advantages of the present methodology is that it allowed the evaluation of three different classic cell viability parameters sequentially, in the same assay, and for the same group of treated cells. The relevance of this difference is evidenced when one considers that the results obtained with a single method may often be misleading due to bias or methodological limitations (16). When employing HGF cells in the multiparametric assessment, differences were observed in the first parameter of cytotoxicity (mitochondrial activity) after $24 \mathrm{~h}$ exposure to the two classes tested, where the ceramic materials (Insync and AC12) presented lower cell viability than the hybrid materials. It is noteworthy that Tassin et al. (12) found improved biocompatibility for PICNs, including Enamic, when employing a similar methodology ( $24 \mathrm{~h}$ exposure and assessment of mitochondrial activity).This method has been standardized by ISO for the evaluation of dental materials and is widely used in the scientific literature.
Among the tested ceramic materials, VITA AC 12 is an alumina-based material, suitable for indirect restorations fabricated with a CAD-CAM system. Alumina has broad clinical use and is usually recommended for anterior and posterior crowns, as well as for previous single-retainer resin-bonded fixed partial dentures (18). The reduced cell survival (61\%) observed in the present study after exposure to this material corroborates previous literature reports that alumina composite materials exhibit in vitro cytotoxic effects (19).

The present study also provides the first literature report assessing the cytotoxicity of InSync. This ceramic material is a layering system indicated for zirconia and lithium disilicate restorations placed in close contact with gingival fibroblasts. In the present study, InSync presented a significant reduction in cell viability, as measured by both $\mathrm{XT}$ and NRU tests with $24 \mathrm{~h}$ extraction.

Vita Enamic (a PICN) presented good in vitro biocompatibility (Fig. 1A, 1B). This result could be explained by the innovative polymerization mode of the material's HTHP (high-temperature and high-pressure) monomers, and its high degree of conversion. In fact, the level of conversion of monomers has been found to influence cellular response (20), corroborating the findings of Gupta et al. (21), who reported that the polymerization of resins influences their cytotoxicity. Unlike most photopolymerizable resins, PICNs do not contain Bis-GMA, a monomer that has shown higher in vitro cytotoxicity to HGFs than other methacrylate monomers (21). In addition, a study comparing CAD/CAM restorative materials found that both resin-infiltrated ceramic (Enamic) and composite resin reinforced with nano-ceramics (Lava Ultimate) showed only minor suffering from grinding-induced chipping damage (22). This finding represents another biological advantage of these ceramiclike materials in clinical practice since these materials can be placed in intimate contact with gingival tissue, as in the case of implant-supported prostheses. Furthermore, it has been established that human gingival fibroblasts attach better to electro-polished than to etched or sandblasted surfaces (23).

Mihali et al. (24) showed that Lava Ultimate, the second hybrid material tested in this study, reduced bone resorption around the implant and did not show occlusal wear after a 3-month period of intraoral evaluation. In the present study, although a decrease in membrane integrity (NRU assay) was observed for Lava Ultimate at the $24 \mathrm{~h}$ extraction, it did not induce cytotoxic levels (cell survival above 70\%) in the two other assays (MTT and CVDE).

However, if these results initially seem to corroborate the idea of a significant difference in cytotoxicity between these classes of materials (dental ceramics and ceramiclike materials), interesting changes in our methodology 
concerning the ISO proposal may reveal a more complex context. No cytotoxic effects were observed for Vita AC12, Lava Ultimate, Vita Enamic and InSync when the materials were submitted to longer extraction times (7 and 40 days), with daily washing. Previous studies reported that the time of extraction could have an impact on the level of cytotoxicity presented by dental materials and medical devices $(16,25)$. Whereas the shorter extraction time of $24 \mathrm{~h}$ corresponds to the early biological impact that could characterize the setting process and the onset of acute adverse effects, extended extraction/washing procedures aim to simulate the fluidic turnover that could occur in the oral environment, where crevicular fluid and saliva may dilute possibly released toxic components. The constant washings for one week (Fig. 1A, B, C) have been able to consistently revert all materials to noncytotoxic levels, which is confirmed when continuity lasts up to 40 days. Therefore, the adequate cell survival rates after washing observed for all tested materials, but not for the positive control (latex), suggests that none of them induces chronical toxicity. It is important to note that an extrapolation of the results of the present study to clinical practice remains restricted by the limitations of in vitro assessments, and further studies should be performed at both the pre-clinical and clinical levels in order to ensure the safety of the dental materials. Nevertheless, these findings can be viewed as positive for the clinical indication of these restorative materials, considering that indirect restorations remain in contact with adjacent soft tissues for extended periods of time.

From these results, we can conclude that Vita Enamic and Lava Ultimate hybrid ceramic-like materials presented better biocompatibility at $24 \mathrm{~h}$ extraction than the $\mathrm{AC} 12$ and InSync ceramic materials. However, after more extended time periods of extraction and daily washing, all tested restorative materials showed a similar absence of cytotoxicity, suggesting adequacy for clinical use.

\section{Resumo}

Este estudo teve como objetivo comparar a citotoxicidade dos materiais restauradores indiretos Vita AC12, Lava Ultimate, Vita Enamic e InSync. Extratos de cada material foram preparados por incubação por 1, 7 e 40 dias, com lavagem diária. Fibroblastos gengivais humanos foram expostos aos extratos e a viabilidade celular foi medida por avaliação sequencial da atividade mitocondrial (XTT), integridade da membrana (NRU) e densidade celular (CVDE). Extratos de esferas de poliestireno e fragmentos de látex foram utilizados como controles negativos e positivos, respectivamente. As diferenças entre os grupos e os tempos experimentais foram avaliadas por análise de variância. Na extração de $24 \mathrm{~h}$, observaram-se diferenças significativas entre o controle e Vita AC-12 e InSync no teste do XT $(p<0,05)$ e entre o controle e os materiais Enamic e Lava Ultimate, no teste CVDE $(p<0,05)$. AC12, Lava Ultimate e InSync apresentaram viabilidade celular significativamente menor do que o Enamic e o grupo controle, no ensaio NRU $(p<0,05)$. Os materiais cerâmicos híbridos Vita Enamic e Lava Ultimate apresentaram melhor biocompatibilidade no ponto de tempo de extração de 24 h do que os materiais cerâmicos AC12 e InSync. No entanto, uma simulação de remoção de componentes tóxicos por fluidos biológicos, realizada com o uso de tempos de extração mais prolongadose lavagem diária, levou à ausência de citotoxicidade em todos os materiais restauradores testados. Esses achados podem ser vistos como positivos para a indicação clínica desses materiais restauradores, considerando seu contato com tecidos macios adjacentes por longos periodos de tempo.

\section{References}

1. Pjetursson $B E$, Sailer I, Zwahlen $\mathrm{M}$, Hammerle $\mathrm{CH}$. A systematic review of the survival and complication rates of all-ceramic and metalceramic reconstructions after an observation period of at least 3 years. Part I: Single crowns. Clin Oral Implants Res 2007;18 Suppl 3:73-85.

2. Wataha JC, Craig RG, Hanks CT. The release of elements of dental casting alloys into cell-culture medium. J Dent Res 1991;70:1014-1018.

3. Gracis S, Thompson VP, Ferencz JL, Silva NR, Bonfante EA. A new classification system for all-ceramic and ceramic-like restorative materials. Int J Prosthodont 2015;28:227-235.

4. Pabst AM, Walter C, Grassmann L, Weyhrauch M, Brüllmann DD, Ziebart T, Scheller H, et al. Influence of CAD/CAM all-ceramic materials on cell viability, migration ability and adenylate kinase release of human gingival fibroblasts and oral keratinocytes. Clin Oral Investig 2014;18:1111-1118.

5. Mainjot AK, Dupont NM, Oudkerk JC, Dewael TY, Sadoun MJ. From artisanal to CAD-CAM blocks: state of the art of indirect composites. J Dent Res 2016;95:487-495.

6. Grenade C, De Pauw-Gillet MC, Gailly P, Vanheusden A, Mainjot A. Biocompatibility of polymer-infiltrated-ceramic-network (PICN) materials with Human Gingival Fibroblasts (HGFs). Dent Mater 2016; 32:1152-1164.

7. Nguyen JF, Ruse D, Phan AC, Sadoun MJ. High-temperature-pressure polymerized resin-infiltrated ceramic networks. J Dent Res 2014;93:6267.

8. Zhi L, Bortolotto $\mathrm{T}$, Krejci I. Comparative in vitro wear resistance of CAD/CAM composite resin and ceramic materials. J Prosthet Dent 2016;115:199-202

9. Sjogren G, Sletten G, Dahl JE. Cytotoxicity of dental alloys, metals, and ceramics assessed by millipore filter, agar overlay, and MTT tests. J Prosthet Dent 2000;84:229-236.

10. Kohal RJ, Weng D, Bachle M, Strub JR. Loaded custom-made zirconia and titanium implants show similar osseointegration: an animal experiment. Journal of Periodontology 2004;75:1262-1268.

11. Messer RL, Lockwood PE, Wataha JC, Lewis JB, Norris S, Bouillaguet S. In vitro cytotoxicity of traditional versus contemporary dental ceramics. J Prosthet Dent 2003;90:452-458.

12. Tassin M, Bonte E, Loison-Robert LS, Nassif A, Berbar T, Le Goff S, et al. Effects of High-Temperature-Pressure Polymerized Resin-Infiltrated Ceramic Networks on Oral Stem Cells. PLoS ONE 2016;19;11:e0155450.

13. Chemical Custom Designed Ceramics [homepage on the Internet]. Connecticut: InSync Ceramic System; [cited 2017 Feb 16]. Available from: http://jensendental.com/wp-content/uploads/2017/02/INSYNCLAYERING-final.pdf

14. ISO 10993-5: Biological Evaluation of Medical Devices. Part 5: Tests for In Vitro Cytotoxicity, 2009.

15. Almeida-Lopes L, Rigau J, Amaro Zângaro R, Guidugli-Neto J, Marques Jaeger MM. Comparison of the low-level laser therapy effects on cultured human gingival fibroblasts proliferation using different irradiance and same fluence. Lasers Surg Med 2001;29:179-184.

16. Scelza $M Z$, Linhares $A B$, da Silva $L E$, Granjeiro JM, Alves GG. A multiparametric assay to compare the cytotoxicity of endodontic sealers with primary human osteoblasts. Int Endod J 2012;45:12-18.

17. Raffaelli L, Rossi lommetti P, Piccioni E, Toesca A, Serini S,Resci F, et al. Growth, viability, adhesion potential, and fibronectin expression in fibroblasts cultured on zirconia or feldspatic ceramics in vitro. J Biomed Mater Res A2008;86:959-968

18. Wassermann A, Kaiser M, Strub JR. Clinical long-term results of VITA InCeram Classic crowns and fixed partial dentures: A systematic literature review. Int J Prosthodont 2006;19:355-363. 
19. Kilic K, Kesim B, Sumer Z, Polat Z, Kesim S. In vitro cytotoxicity of all-ceramic substructural materials after aging. J Dent Sci 2013;8:e231-e238.

20. Lin-Gibson S, Sung L, Forster AM, Hu H, Cheng Y, Lin NJ. Effects of filler type and content on mechanical properties of photopolymerizable composites measured across two-dimensional combinatorial arrays. Acta Biomater 2009;5:2084-2094.

21. Gupta SK, Saxena P, Pant VA, Pant AB. Release and toxicity of dental resin composite. Toxicol Int 2012;19:225-234.

22. Curran $P$, Cattani-Lorente $M$, Anselm Wiskott HW, Durual $S$, Scherrer SS. Grinding damage assessment for CAD-CAM restorative materials. Dent Mater 2017;33:294-308.
23. Könönen $M$, Hormia M, Kivilahti J, Hautaniemi J, Thesleff I. Effect of surface processing on the attachment, orientation, and proliferation of human gingival fibroblasts on titanium. J Biomed Mater Res 1992;26:1325-1341.

24. Mihali S, Bortun C, Bratu E. Nano-ceramic particle reinforced compositeLava Ultimate CAD/CAM restorative. Rev Chem 2013;64,435-437.

25. Li W, Zhou J, Xu Y. Study of the in vitro cytotoxicity testing of medical devices. Biomed Rep 2015;3:617-620.

Received December 18, 2017 Accepted June 4, 2018 